\title{
Clinical and laboratory variables associated with mortality outcome in the post-operative pediatric cardiac surgery
}

\author{
Variáveis clínicas e laboratoriais associadas ao desfecho mortalidade no pós-operatório de cirurgia \\ cardíaca pediátrica

\section{Variables clínicos y laboratorios asociados al desfecho mortalidad en el post-operatorio de cirugía cardíaca pediátrica}

Aline Cerqueira Santos Santana da Silva ${ }^{1}$ (D) Marluci Andrade Conceição Stipp ${ }^{1}$ (1) Fernanda Maria Vieira Pereira ${ }^{1}$ (D) Graciele Oroski Paes ${ }^{1}(10)$

Virginia Maria de Azevedo Oliveira Knupp ${ }^{1,2}$ (C)

1. Universidade Federal Fluminense.

Rio das Ostras, RJ, Brasil.

2. Universidade Federal do Estado do Rio de Janeiro. Rio de Janeiro, RJ, Brasil.
Corresponding author:

Aline Cerqueira Santos Santana da Silva. E-mail: alinecer2014@gmail.com

Submitted on $05 / 16 / 2018$.

Accepted on 09/27/2018.

DOI: 10.1590/2177-9465-EAN-2018-0147

\begin{abstract}
Objective: To identify clinical and laboratory variables associated with mortality outcome in the post-operative pediatric cardiac surgery. Method: Descriptive, retrospective study carried out in three reference centers in Rio de Janeiro State, Brazil, from the collection in 120 medical reports of children with Congenital Heart Disease undergoing surgery. Data were analyzed by using central tendency measures and association tests between variables and mortality. $p<0.05$ was considered. Results: We observed the mortality outcome in $10(7.2 \%)$ of the children after analyzing all medical records. The dialysis and extracorporeal circulation times, aortic and surgical clamping variables were associated with mortality outcome $(p<0.05)$. Conclusion and implications for practice: The identification of these variables is a major factor for the control of the main post-operative complications, allowing the recognition of subtle clinical alterations requiring attention and immediate intervention with consequent reduction of mortality.
\end{abstract} Keywords: Heart Diseases; Intensive Therapy; Pediatric Nursing; Thoracic Surgery.

\section{Resumo}

Objetivo: Identificar as variáveis clínicas e laboratoriais associadas ao desfecho mortalidade no pós-operatório de cirurgia cardíaca pediátrica. Método: Estudo descritivo, retrospectivo realizado em três centros de referência no estado do Rio de Janeiro a partir da coleta em 120 prontuários de crianças portadoras de cardiopatia congênita, submetidos a cirurgia. Os dados foram analisados utilizando-se medidas de tendência central e testes de associação entre as variáveis e mortalidade. Considerou-se $p<0,05$. Resultados: Do total de prontuários analisados, o desfecho mortalidade foi observado em 10 (7,2\%) das crianças. As variáveis diálise e os tempos de circulação extracorpórea, clampeamento aórtico e cirúrgico apresentaram associação com a mortalidade $(p<0,05)$. Conclusão e implicações para a prática: A identificação dessas variáveis configura fator preponderante para o controle das principais complicações decorrentes do pós-operatório, possibilitando o reconhecimento de alterações clínicas sutis exigindo atenção e intervenção imediata com consequente redução da mortalidade.

Palavras-chave: Cardiopatias; Terapia Intensiva; Enfermagem Pediátrica; Cirurgia Torácica.

\section{Resumen}

Objetivo: Identificar las variables clínicas y de laboratorio asociadas con lo desfecho mortalidad en el post-operatório de cirugía cardíaca pediátrica. Método: Estudio descriptivo, retrospectivo, realizado en tres centros de referencia del estado de Rio de Janeiro a partir de la recolección de datos en 120 prontuarios de niños portadores de cardiopatía congénita, sometidos a cirugía. Los datos fueron analizados utilizando medidas de tendencia central y pruebas de asociación entre variables y mortalidad. Se consideró $p<0,05$. Resultados: Lo desfecho mortalidad fue observada en $10(7,2 \%)$ niños, del total de prontuarios analizados Las variables diálisis y los tiempos de circulación extracorpórea, engrape aórtico y quirúrgico, presentaron asociación con lo desfecho mortalidad $(p<0,05)$. Conclusión e implicaciones para la práctica: La identificación de esas variables configura factor preponderante para el control de las principales complicaciones derivadas del post-operatorio, posibilitando el reconocimiento de alteraciones clínicas sutiles exigiendo atención e intervención inmediata con consecuente reducción de la mortalidad.

Palabras clave: Enfermedad del Corazón; Terapia Intensiva; Enfermería Pediátrica; Cirugía Torácica. 


\section{INTRODUCTION}

Congenital Heart Diseases (CHD) result from changes in the structure and functioning of the heart of newborns, characterized by a group of lesions divergent with normality that cause hemodynamic activities to be altered. ${ }^{1}$

The etiology of CHD is still complex and without full knowledge of its cause by researchers in the field. It can be inferred that CHD originates from the association of factors, that is, it may be related to possible alterations due to the genetic nature and certain predisposing environmental factors. ${ }^{2}$ Thus, CHD accounts for $40 \%$ of all congenital defects, being considered one of the most frequent malformations. ${ }^{3}$

In spite of the important representation of $\mathrm{CHD}$ in childhood in several regions of Brazil, great difficulties are still encountered to carry out its diagnosis and treatment. This fact can be explained by several factors, such as the lack of specialized professionals, difficulty in accessing health services, defects that go unnoticed during the physical examination, the age of the analyzed population, and the non-inclusion of minor cardiac defects, leading to false low-incidence interpretation. ${ }^{4}$

Thus, international studies show a fluctuation in the incidence of CHD, ranging from 4-14/1000 to 2-10/1000 Live Births (LB). ${ }^{1-5}$ In Brazil, it is believed that this condition affects about $0.9 \%$ of $L B$, where 20 to $30 \%$ are serious structural defects. However, their true incidence and distribution in developing regions are not known. ${ }^{6}$

In view of the above, $\mathrm{CHD}$ represents a heterogeneous group of lesions with severe and varied hemodynamic consequences, requiring early recognition due to its prognostic implication, rapid clinical deterioration and consequent mortality. It is known that about 20 to $30 \%$ of this population dies in the first month of life due to complications such as heart failure or hypoxia. ${ }^{2}$

Thus, CHD still represents a serious public health problem in Brazil and in the world, standing out as the first cause of death among all congenital malformations. These defects amount to about 3 to 6/1000 LB, requiring different follow-ups and interventions, ${ }^{1}$ therefore configuring an important cause of admission and mortality in pediatric units.

Most congenital heart defects are corrected through surgery, which represents a highly complex and commonly long-lasting procedure, with Extracorporeal Circulation (ECC) being used in $90 \%$ of the cases. ${ }^{7,8}$

Thus, the postoperative period of $\mathrm{CHD}$ involves a series of care carried out by the health team, among which the hemodynamic monitoring of clinical parameters, which undergo changes according to the type of heart disease and the postoperative recovery. ${ }^{5}$

In order to enable the clinical recovery of this clientele, the units use a variety of strategies, such as the establishment of protocols, indicators and severity indexes, as well as the monitoring of clinical and laboratory variables as a way of measuring the severity and complexity of the care provided, based on clinical manifestations and patient evolutions based on the levels of care provided to them. ${ }^{5}$

Based on the above, the following question should be highlighted: which clinical and laboratory variables are associated with the mortality outcome in the postoperative period of pediatric cardiac surgery?

Currently, the adoption of risk stratification and therapeutic protocols is well defined for adults, these indicators, not yet applied in Pediatrics, which should cover the variety of anatomicphysiological conditions, the underlying disease and contemplate various surgical techniques used, among other factors. ${ }^{9}$

Given the severity and specificity that the postoperative period of cardiac surgery corresponds to, any initiative that favors concrete action in this sphere, such as the adoption of innovations in health services, seeks to make possible improvements in clinical practice applied to the patient, which in addition to predicting mortality, makes it possible to identify in a timely manner clinical alterations.

This study aimed to identify clinical and laboratory variables associated with the mortality outcome in the postoperative period of pediatric cardiac surgery.

\section{METHOD}

This is a descriptive, retrospective, quantitative approach, and also an integral part of the research called "Protótipo do instrumento de risco para predizer mortalidade da criança cardiopata: uma ferramenta para o gerenciamento do cuidado", developed in three reference centers in cardiac surgery in Rio de Janeiro State.

The specialized centers were characterized as quaternary institutions of reference in the diagnosis and treatment of $\mathrm{CHD}$. These centers provide high complexity care as a definitive correction of $\mathrm{CHD}$ using ECC and Extracorporeal Membrane Oxygenation (ECMO).

Data collection was performed in a total of 120 medical reports of children with $\mathrm{CHD}$, hospitalized in the postoperative units from 2011 to 2014, and submitted to surgical correction with ECC. Patients who underwent surgical correction without ECC and medical records with incomplete data were excluded.

A sample of the number of cardiac surgeries performed in the temporal cut-off that corresponded to the study period (2011 to 2014) was necessary to estimate the average number of charts collected at each center. Afterwards, an average of surgeries between the centers was calculated.

Sampling was performed to determine the number of medical records collected at each center, using the following parameters: margin of error of $5 \%$, confidence interval of $95 \%$, population of 825 surgeries and percentage of average mortality of the studied population of $10 \%$. The number of records obtained in the sampling process was divided proportionally by the institutions according to the number of surgeries performed at each center in order to avoid bias in data collection. 
The age and weight of the children and the following clinical variables in the postoperative period of cardiac surgery were collected from the charts: temperature, average blood pressure pressure, arrhythmias, dialysis, ventilatory support time and laboratory variables - blood glucose, lactate, gasometry, coagulogram, urea, creatinine, electrolytes and PTT. We also collected information regarding ECC time, deep hypothermic circulatory arrest, aortic clamping, and surgical time.

A database was constructed for the calculation of measures of central tendency (mean, median, standard deviation and interquartile range). Verification of the degree of association between variables and mortality was calculated, respectively, for categorical variables with Fisher's Exact Test, and for the Student's t-Test and Mann-Whitney was used to verify the normal distribution pattern. The value of $p \leq 0.05$ was adopted.

All ethical aspects were contemplated in accordance with Resolution No. 466 of 2012 of the National Health Council (Conselho Nacional de Saúde), with an approved Opinion 187139 and CAAE (Certificate of Presentation for Ethical Consideration) 04680012.2 .0000 .5238

\section{RESULTS}

The median age of the children was 11 months, with a minimum of 2 months and a maximum of 2 years. Regarding weight, the median comprised $3.8 \mathrm{~kg}$, ranging from 3.6 to $7.9 \mathrm{~kg}$. The mortality outcome was observed in $10(7.2 \%)$ of the children after analyzing all records.

Table 1 presents the clinical variables of children related to the mortality outcome. The dialysis variable in the postoperative presented a statistically significant difference $(p<0.05)$, that is, the majority of the children who died were submitted to this procedure. Another indicator that presented a statistically significant difference was ventilatory suport. From all records analyzed, 52 children underwent ventilatory support for more than 24 hours, and eight (15.4\%) of these children died.
Table 2 presents the comparison between death and nondeath outcome between clinical and laboratory variables. The postoperative dialysis and cardiopulmonary bypass, aortic and surgical clamping variables were associated with the mortality outcome $(p<0.05)$.

\section{DISCUSSION}

In the last decades, there has been a great increase in relation to the surgical correction of $\mathrm{CHD}$, due to the high incidence, in which an estimated 10 out of every 1000 LB are affected by some type of congenital anomaly, where one third is diagnosed requiring surgical intervention. ${ }^{10}$

The median age of children undergoing surgical intervention was eleven months, ranging from two months to two years of age. Similar data correlate with the findings of one study, ${ }^{11}$ in which the mean age of children with CHD was 2 years and 3 months. The clinical manifestation of $\mathrm{CHD}$ depends fundamentally on the anatomical alteration, and usually the most severe manifestations usually occur in the first year of life.

Pediatric cardiac surgery involves a range of procedures, with curative or palliative purposes, performed in different types of $\mathrm{CHD}$, which may lead to the appearance of some complications, especially in the postoperative period. ${ }^{12}$ In view of this context, it was possible to observe the behavior of some clinical variables, among them Acute Renal Insufficiency (ARF), which involved dialysis with association for the outcome mortality.

ARF has been recorded over time as an important complication of cardiac surgery in children and is related to a serious prognosis for these patients. It is one of the most prevalent and harmful complications presented in the postoperative period of cardiac surgery and, even with the optimization performed in the preoperative phase of renal function, of tissue perfusion during ECC, of the volume balance, as well as the indication dialytic therapy, is still limited to the repercussions caused by ECC. ${ }^{13}$

Table 1. Distribution of the clinical variables of the children undergoing cardiac surgery $(n=120)$ related to the mortality outcome. Rio de Janeiro city, RJ, Brazil, 2014.

\begin{tabular}{lcccc}
\hline Variables & Answers & Death N (\%) & Non-death N (\%) & p value* \\
\hline \multirow{2}{*}{ Presence of arrhythmia } & Yes & $1(10.0)$ & $9(90.0)$ & 0.543 \\
Post-Operative Dialysis & No & $9(7.1)$ & $118(92.9)$ & \\
Vestilatory Support & No & $5(83.3)$ & $1(16.7)$ & $<0.05$ \\
Time** & $>24 \mathrm{hs}$ & $8(15.2)$ & $115(95.8)$ & \\
\hline
\end{tabular}

Source: research data. ${ }^{*}$ Fisher's Exact Test; ${ }^{* *}$ variable presenting missing. 
Table 2. Comparison between the death and non-death outcomes between clinical and laboratory variables. Rio de Janeiro city, RJ, Brazil, 2014.

\begin{tabular}{|c|c|c|c|}
\hline Variables & $\begin{array}{c}\text { Value obtained } \\
\text { Death }\end{array}$ & $\begin{array}{c}\text { Value obtained } \\
\text { Non-death }\end{array}$ & $p$ value \\
\hline Preoperative ACT & 142.00 & 131.50 & 0.34 \\
\hline Age & 0.12 & 1.00 & $<0.05$ \\
\hline Bicarbonate level at SC discharge & 18.40 & 19.90 & $<0.05$ \\
\hline Urea level at SC discharge & 29.00 & 25.00 & 0.79 \\
\hline Blood glucose level at SC discharge & 194.0 & 181.5 & 0.58 \\
\hline Lactate within 24 hours & 4.6 & 1.3 & $<0.05$ \\
\hline Lactate level at SC discharge & 7.1 & 2.8 & $<0.05$ \\
\hline Deep hypothermic circulatory arrest & 28.00 & 32.00 & 0.20 \\
\hline Clamping time & 107.50 & 55.00 & $<0.05$ \\
\hline ECC time & 156.50 & 79.00 & $<0.05$ \\
\hline Surgery time & 316.00 & 209.00 & $<0.05$ \\
\hline Temperature within 24 hours & 35.80 & 36.20 & $<0.05$ \\
\hline Temperature at SC discharge & 35.30 & 35.80 & 0.12 \\
\hline ABP within 24 hours & 62.00 & 76.50 & $<0.05$ \\
\hline ABP level at SC discharge & 64.40 & 73.84 & 0.15 \\
\hline
\end{tabular}

Source: research data. * Mann-Whitney; T-Test; SC: Surgical Center ABP: Average Blood Pressure pH: Potential Hydrogen; PTT: Partial Thromboplastin Time; ACT: Activated Clotting Time; ECC: Extracorporeal Circulation. Reference value: Bicarbonate: (22 to $26 \mathrm{mEq} / \mathrm{l})$; Creatinine $(0,40$ to $0,90 \mathrm{mg} / \mathrm{dl}) ; \mathrm{Urea}(10$ to 40 mg/dl); Blood glucose: (70-99 mg/dl); Lactate: (1mmol/L); Potassium: (3,5 to 5.5mEq/l); PTT (30 to 50'); ECC Time (90'); Clamping Time (90') ${ }^{13}$; TCA: (5-10').

This fact may be related to its difficult identification in the preoperative period, considering that it presents subclinically in most cases. In this way, when it manifests itself, it means potential source of post-surgical morbidity and mortality. ${ }^{13}$

In order to solve this issue, several urine biomarkers ${ }^{14,15}$ that reflect ARF have recently been investigated to facilitate early diagnosis, however, it is still necessary to identify risk factors that are clinically modifiable.

Taking as a premise the identification of modifiable risk factors as therapeutic goals to prevent ARF in the postoperative period of cardiac surgery in pediatric patients, a study ${ }^{16}$ was developed at the University of South Korea, which aimed to determine the potential of modifiable risk factors between transfusions and laboratory variables that can identify patients who are at high risk for ARF after pediatric cardiac surgery.

This study concluded that the low hemoglobin concentration in the preoperative period was independently associated with ARF in the postoperative period of cardiac surgery, in addition to previously known risk factors such as prolonged ECC and younger age. It was possible to observe that when there is an increase in hemoglobin concentrations in the postoperative period, compared to preoperative hemoglobin concentrations, it remains an independent predictor of ARF, suggesting the possible contribution of hemoconcentration.

However, we should emphasize that prospective trials should be performed to evaluate whether the correction of preoperative anemia and prevention of hemoconcentration can improve postoperative ARF in patients undergoing congenital cardiac surgery. ${ }^{16}$

Among the data collected in this study, it was possible to correlate the dialysis ratio to the variables related to weight, age, surgical time, ECC time, clamping, diagnosis, and blood glucose control. Although dialysis therapy was an early recommended procedure, most of the children in this study who underwent this procedure to recover renal function died.

Regarding the ventilation support time variable, it also stood out in relation to the mortality outcome. However, it is postulated that this event is more intensified in patients with cardiac abnormalities due to insufficient or improper growth of the heart during fetal development. ${ }^{17}$ 
In this regard, it is possible to observe that these patients, in addition to the risks themselves inherent in surgical intervention, such as readpassing to changes in pulmonary flow in postoperative period and extended exposure to ECC, should be considered other actors, such as weight, prematurity and age.

According to a retrospective study carried out in Italy, ${ }^{17}$ these patients are also at increased risk of infection by viruses or bacteria, becoming a recurrence in lung infections, more than any other population, corresponding to a high frequency of hospitalizations, appointment with specialists, comorbidities and high mortality, when submitted to the correction of cardiac defects.

Another aspect observed was the relation with the decrease of sodium bicarbonate both at the exit of the surgical center and in the first 24 hours postoperative of cardiac surgery, however, this data was not very specific, suggesting a mild metabolic acidosis, common in this period.

Gasometric control is one of the most performed exams in patients in the postoperative period of pediatric cardiac surgery as a method of adequacy of mechanical ventilation and weaning, as well as the diagnosis of acid-base balance disorders, making its determination serial confirm the efficacy of any therapeutic measures. ${ }^{18}$

Thus, in this study, it was possible to observe the negative influence of ECC time on renal function by increasing serum creatinine,${ }^{13}$ and its variation, corresponding to a higher incidence of dialysis among patients with increased ECC time.

The ECC increasingly is configured as state-of-the-art technology, allowing correction in inoperable patients; however, its effects have not yet been defined, which makes its action speculative in the organism. ${ }^{8}$ Therefore, its prolonged time is associated to the development of complications.

Another important aspect under this variable is the combination of pre-existing risk factors among CHD patients, such as age, gender and underlying diseases, ${ }^{7}$ making newborns and children more vulnerable to the development of harmful complications such as injury acute renal failure.

Glucose presented a high rate both at the time of exiting the surgical center and in the first 24 hours. This fact is reserved to the perioperative period of the cardiac surgery commonly understood as a period that represents a crucial moment in the evolution of this child. During this period, patients undergo significant variations in blood volume, body temperature, plasma composition and blood flow, corresponding to important pathophysiological consequences. ${ }^{19}$

The hyperglycemia generated was, for a long time, an undervalued indicator and interpreted as a secondary event, and today it is recognized as a predictive factor of poor prognosis in the critical patient. Thus, it is expected that the elevation of blood glucose is an early biological marker in the surgical clinical evolution, making it possible to identify the at-risk population in the intraoperative period. ${ }^{19}$

Analyzing serum lactate, increased values are observed at the exit of the surgical center, where the elevation of these indices can occur with or without concomitant metabolic acidosis. According to one study, ${ }^{18}$ hyperlactatemia is considered mild to moderate (2 to $5 \mathrm{mmol} / \mathrm{L}$ ) when there is no metabolic acidosis, whereas in lactic acidosis there is a marked and persistent elevation of serum lactate ( $>5 \mathrm{mmol} / \mathrm{LL}$ ) associated with metabolic acidosis.

Follow-up of serum lactate becomes a preponderant action in the postoperative period of cardiac surgery for severa reasons, such as the development of lactic acidosis resulting from tissue hypoperfusion of the effect of certain drugs or innate defects in carbohydrate metabolism. Another factor is the difficult identification of clinical findings of initial hypoperfusion in critical patients, when the possibility of reversion of the condition would be greater. And even when lactate levels may be higher than the reference values even though the patient is hemodynamically stable. Thus, serum lactate elevation is characterized as an early prognostic indicator of mortality. ${ }^{18}$

Regarding the laboratorial PTT variable, according to the literature,$^{20}$ there is no positive predictive value to identify the development of complications, such as the occurrence of bleeding during surgery or in the postoperative period. However, it is recommended that it should be followed up with a procedure that may induce hemostatic disorders (cardiopulmonary bypass), or when using antiplatelet agents or anticoagulant agent such as protamine during ECC.

All the patients in the analyzed charts were submitted to surgical intervention, in which the mean duration of the surgery, the ECC time and the clamping time were associated with the mortality outcome.

Despite the possible complications, the surgical correction seeks, whenever possible, definitive correction of the congenital defect, symptom control, improvement of the quality of life and prevention of future injuries. ${ }^{21}$

However, it is known that additional, sometimes unavoidable, assaults such as ECC and total circulatory arrest contribute to further aggravate the body imbalance in the intraoperative period. The combination of these factors contributes to the body's development of defense mechanisms defined as "NeuroEndocrine-Immuno-Metabolic Response to Trauma" in order to resist the initial harmful event. ${ }^{19}$

Clamping times and ECC, according to the complexity of some Heart Diseases, become prolonged, being important to signal that a time of ECC and aortic clamping greater than 90 to 60 minutes, respectively, increases the morbidity and mortality of this age segment. ${ }^{12}$ 


\section{CONCLUSIONS AND IMPLICATIONS FOR PRACTICE}

The identification of the clinical and laboratory variables associated with the mortality outcome, with emphasis on dialysis, prolonged ECC, aortic and surgical clamping, is a major factor for the control of the main complications arising from the immediate postoperative period and consequent reduction in the mortality of children undergoing cardiac surgery.

Thus, the association of these variables and their relation to the mortality outcome is presented as a major implication in the clinical practice of Nursing in the face of the complex phenomenon that is to take care of the critically ill and hospitalized cardiac child, where the actual needs presented by it will require the performance of strategies of action and interaction, supported by reciprocity, completeness and recursiveness.

So, it is necessary to adopt therapeutic procedures, such as the reduction of mechanical ventilation time, the reduction of aortic clamping time and ECC, aiming at the timely treatment of complications resulting from the postoperative period of cardiac surgery, aiming to reduce the mortality that presents as a challenge for these patients.

From this point of view, it will be possible to detect early injuries resulting from the surgical procedure, which will enable the health team, especially Nursing, to recognize subtle clinical alterations, requiring attention and immediate intervention through the measurement of these variables, aiming to reduce complications and mortality.

As a limitation of the study, the difficulties to obtain the data due to the lack of information records in some of the charts in the studied centers were highlighted, as well as updated scientific evidence in the pediatric age group that approached laboratory variables, in relation to cardiac surgery, for example, PTT. Therefore, there is a need for continuity or the emergence of new approaches on this subject in order to allow performance comparison, with demonstration of results between the different centers of pediatric cardiology.

\section{REFERENCES}

1. Trevisan P, Rosa RFM, Koshiyama DB, Zen TD, Paskulin GA, Zen PRG. Cardiopatias congênitas e cromossomopatias detectadas por meio do cariótipo. Rev Paul Pediatr [Internet]. 2014 Jun;32(2):26271. Available from: http://www.scielo.br/scielo.php?pid=S010305822014000200262\&script=sci_arttext\&tlng=pt

2. Bastos LF, Araújo TM, Frota NM, Caetano JA. Perfil Clínico e Epidemiológico de Crianças com Cardiopatias Congenitas Submetidas à Cirurgia Cardíaca. Rev Enferm UFPE On Line (Recife) [Internet]. 2013 Aug;7(8):5298-304. Available from: https://periodicos.ufpe.br/revistas/ revistaenfermagem/article/viewFile/11806/14191

3. Rosa RCM, Rosa RFM, Zen PRG, Pauskulin GA. Cardiopatias congênitas e malformações extracardíacas. Rev Paul Pediatr [Internet]. 2013;31(2):243-51. Available from: http://www.scielo.br/scielo. php?pid=S0103-05822013000200017\&script=sci_abstract\&tlng=pt
4. Mattos SS, Regis CT, Mourato FA, Hatem TP, Freitas CPG, Gomes RGS, et al. Busca ativa por cardiopatias congênitas é factível? Experiência em oito cidades Brasileiras. Int J Cardiovasc Sci [Internet]. 2015;28(2):95100. Available from: http://www.onlineijcs.org/sumario/28/pdf/ v28n2a03.pdf

5. Hoscheidt LM, Moraes MAP, Witkowski MC. Complexidade dos cuidados de enfermagem em crianças submetidas à cirurgia cardíaca. Rev Pesq Saúde [Internet]. 2014 Jan/Apr; [cited 2015 Sep 5]; 15(1):2003-7. Available from: http://www.periodicoseletronicos.ufma. br/index.php/revistahuufma/article/view/3049/4080

6. Araújo JSS, Régis CT, Gomes RGS, Silva CS, Abath CMB, Mourato FA, et al. Congenital heart disease in northeast Brazil: 10 consecutive years of records in Paraiba state, Brazil. Rev Bras Cardiol [Internet]. 2014 Jan/ Feb;27(1):13-9. Available from: http://www.onlineijcs.com/detalhes/3/ congenital-heart-disease-in-northeast-brazil--10-consecutive-yearsof-records-in-paraiba-state--brazil

7. Oliveira JMA, Silva AMF, Cardoso SB, Lima FF, Zierer MS, Carvalho ML. Complicações no pós-operatório de cirurgia cardiovascular com circulação extracorpórea. Rev Interd [Internet]. 2015 Jan/Feb;8(1):9-15. Available from: https://revistainterdisciplinar.uninovafapi.edu.br/index. php/revinter/article/view/584

8. Penny DJ, Shekerdemian LS. The American Heart Association's recent scientific statement on cardiac critical care: implications for pediatric practice. Congenit Heart Dis [Internet]. 2013 Jan/Feb;8(1):3-19. Available from: https://www.ncbi.nlm.nih.gov/pubmed/23280102

9. Clavería C, Cerda J, Becker P, Schiele C, Barreno B, Urcelay G, et al. Mortalidad operatoria y estratificación de riesgo en pacientes pediátricos operados de cardiopatía congénita: experiencia de 10 años. Rev Chil Cardiol [Internet]. 2014; [cited 2015 Aug 3]; 33:11-9. Available from: https://scielo.conicyt.cl/pdf/rchcardiol/v33n1/art01.pdf

10. Bertoletti1 J, Marx GC, Hattge Júnior SP, Pellanda LC. Qualidade de vida e cardiopatia congênita na infância e adolescência. Arq Bras Cardiol [Internet]. 2014;102(2):192-8. Available from: http://www. scielo.br/scielo.php?pid=S0066-782X2014000200032\&script=sci_ abstract\&tlng=pt

11. Belo WA, Oselame GB, Neves EB. Perfil clínico-hospitalar de crianças com cardiopatia congênita. Cad Saúde Colet [Internet]. 2016;24(2):21620. Available from: http://www.scielo.br/scielo.php?pid=S1414462X2016000200216\&script=sci_abstract\&tlng=pt

12. Fuentes-Mallozzi DA, Landín-Robles R, Luque-Fernández D, GonzálezOchoa CB, López-Muñiz LR, Treto-Velázquez E. Cirugía cardiaca en pediatría: primer año de experiencia en una unidad de cuidados intensivos pediátricos. Evid Med Invest Salud [Internet]. 2014 Jul/Sep; [cited 2015 Aug 5]; 7(3):119-22. Available from: http://www.medigraphic. com/pdfs/evidencia/eo-2014/eo143e.pdf

13. Moura EB, Bernardes Neto SCG, Amorim FF, Viscardi RC. Correlação do EuroSCORE com o surgimento de lesão renal aguda pós-operatória em cirurgia cardíaca. Rev Bras Ter Intensiva [Internet]. 2013;25(3):2338. Available from: http://www.scielo.br/scielo.php?pid=S0103507X2013000300233\&script=sci_abstract\&tlng=pt

14. Westhoff JH, Tönshoff B, Waldherr S, Pöschl J, Teufel U, Westhoff TH, et al. Urinary Tissue Inhibitor of Metalloproteinase-2 (TIMP-2) • InsulinLike Growth Factor-Binding Protein 7 (IGFBP7) Predicts Adverse Outcome in Pediatric Acute Kidney Injury. PLoS One [Internet]. 2015 Nov;10(11):e0143628. Available from: https://www.ncbi.nlm.nih.gov/ pubmed/26606754

15. Meersch M, Schmidt C, Van Aken H, Rossaint J, Görlich D, Stege D, et al. Validation of cell-cycle arrest biomarkers for acute kidney injury after pediatric cardiac surgery. PLoS One [Internet]. 2014 Oct;9(10):e110865. Available from: https://www.ncbi.nlm.nih.gov/pubmed/25343505

16. Park SK, Hur M, Kim E, Kim WH, Park JB, Kim Y, et al. Risk factors for acute kidney injury after congenital cardiac surgery in infants and children: A retrospective observational study. PLoS One [Internet]. 2016 Nov; [cited 2015 Aug 5]; 11(11):e0166328. Available from: https://www. ncbi.nlm.nih.gov/pubmed/27832187 
17. Pongiglione G, Possidoni A, di Luzio Paparatti U, Costanzo AM, Gualberti $\mathrm{G}$, Bonvicini $\mathrm{M}$, et al. Incidence of Respiratory Disease During the First Two Years of Life in Children with Hemodynamically Significant Congenital Heart Disease in Italy: A Retrospective Study. Pediatr Cardiol [Internet]. 2016 Dec;37(8):1581-9. Available from: https://www.ncbi.nlm. nih.gov/pubmed/27573216

18. Atik FA. Monitorização hemodinâmica em cirurgia cardíaca pediátrica. Arq Bras Cardiol [Internet]. 2004 Feb;82(2):199-208. Available from http://www.scielo.br/scielo.php?script=sci_arttext\&pid=S0066 $782 X 2004000200014$
19. Alves RL, Cerqueira MP, Kraychete NCC, Campos GO, Martins MJ, Módolo NSP. Glicemia perioperatória e complicações pós-operatórias em cirurgia cardíaca pediátrica. Arq Bras Cardiol [Internet]. 2011 Oct [cited 2015 Aug 13]; 97(5):199-208. Available from: http://www.scielo. br/scielo.php?script=sci_arttext\&pid=S0066-782X2011001400003

20. Carvalho JMP, Pinto LAM. Avaliação pré-operatória pediátrica. Rev Hosp Uni Pedro Ernesto [Internet]. 2007 Jul/Dec;6(2):82-9. Available from: http://revista.hupe.uerj.br/detalhe_artigo.asp?id=219

21. Aragão JA, Mendonça MP, Silva MS, Moreira AN, Aragão MECS, Reis FP. O perfil epidemiológico dos pacientes com cardiopatias congênitas submetidos à cirurgia no hospital do coração. Rev Bras Ciênc Saúde [Internet]. 2013; [cited 2015 Aug 5]; 17(3):263-8. Available from: http:// periodicos.ufpb.br/ojs/index.php/rbcs/article/view/13221/9808 